\title{
Recent rates of mesquite establishment in the northern Chihuahuan Desert
}

\author{
R.P. GIBBENS, R.F. BECK, R.P. MCNEELY, AND C.H. HERBEL
}

Authors are range scientist, USDA-ARS, Jornada Experimental Range; professor and range technician, Animal and Range Science Dep., New Mexico State University, Las Cruces; and collaborator, USDA-ARS.

\begin{abstract}
Honey mesquite (Prosopis glandulosa Torr. var. glandulosa populations continue to expand and become more dense, even on areas once "successfully" treated either with herbicides or by bulldozing in southern New Mexico. Areas treated from 1958-1964 for mesquite control on the USDA-ARS Jornada Experimental Range and the New Mexico State University College Ranch were sampled to determine mesquite density changes. On herbicide treated areas sampled in 1976 and again in 1988, mesquite densities increased $10 \%$ to $128 \%$ and had densities from 67 to $494 \mathrm{plants} / \mathrm{ha}$. Two areas treated by either bulldozing or fenuron in 1959-60, and with original kills near $100 \%$, had an average density of 377 plant$\mathrm{s} / \mathrm{ha}$ by 1988 , with an establishment rate of $13.5 \mathrm{plants} / \mathrm{ha} / \mathrm{year}$. On the College Ranch, mesquite densities increased $11 \%$, from 130 (1982) to 147 (1988) plants/ha. Only 19\% of a cohort of mesquite seedlings which germinated in 1989 were still alive in May 1990. Even though only a small percentage of the mesquite that germinated survived into the second year, this is enough to change former grasslands into mesquite-dominated rangelands.
\end{abstract}

Key Words: Prosopis glandulosa, arid rangelands, shrub invasion, desert grasslands, seedling establishment

The historical increase of shrubs on western rangelands has been well documented (Buffington and Herbel 1965, York and DickPeddie 1969). Vast areas of former grasslands in the Chihuahuan and Sonoran Deserts are now dominated by shrubs. Honey mesquite (Prosopis glandulosa Torr. var glandulosa) has been one of the principal shrubs encroaching on grasslands occupying sandy soils in the Chihuahuan Desert. Velvet mesquite ( $P$. velutina Wooton) has a similar role in the Sonoran Desert (Humphrey and Mehrhoff 1958, Hastings and Turner 1965, Martin and Turner 1977).

Mesquite seeds are being continually scattered over rangelands in cow pats (Brown and Archer 1987) and are frequently left in rodent caches (Reynolds and Glendening 1949). Mesquite germinates and establishes over a range of soil water regimes (Scifres and Brock 1969, Scifres and Brock 1971), light regimes (Scifres et al. 1973), and soil types (Ueckert et al. 1979). While in some cases, stands of grasses reduce mesquite seed germination and establishment (Glendening and Paulsen 1955), in other situations, mesquite seeds germinate and seedlings survive in grass stands, even those long-protected from grazing by livestock (Brown and Archer 1989). Higher rates of mesquite establishment have been found on plots protected from grazing by cattle and rabbits than on areas

\footnotetext{
The use of trade names does not constitute an official endorsement or approval of the United States Department of Agriculture.

Appreciation is expressed to James M. Lenz who assisted with data collection in 1988 .

Published as journal article 1596, New Mexico State University Agricultural Experiment Station.

Manuscript accepted 17 Mar. 1992.
}

open to these animals (Glendening 1952). Large mesquite plants are fire-resistant, but mesquite plants $<1.5 \mathrm{yr}$ old are easily killed by fire (Wright and Bailey 1982), and it is quite possible that fire played a role in suppressing mesquite in pristine grasslands (Humphrey 1958). Long-established plots have shown that mesquite has increased in density in spite of drought, herbicide treatment, and protection from grazing (Wright 1982).

This study was undertaken to determine if honey mesquite is continuing to increase on remnant grasslands in the northern Chihuahuan Desert during the period 1958 to 1988.

\section{Materials and Methods}

This study was conducted on the Jornada Experimental Range (JER) and the adjacent New Mexico State University College Ranch (CR) $37 \mathrm{~km}$ north of Las Cruces, N.M. Both properties lie principally on undulating plains of the closed Jornada Basin at an elevation of about $1,260 \mathrm{~m}$. Mean monthly maximum temperatures are highest in June $\left(36^{\circ} \mathrm{C}\right)$ and lowest in January $\left(13^{\circ} \mathrm{C}\right)$. Long-term (1915-1990) average annual precipitation is $259 \mathrm{~mm}$ with $52 \%$ occurring in July, August, and September. Summer precipitation is mostly from high intensity, short-duration, convective storms covering small areas. Winter precipitation comes from low-intensity frontal storms covering broad areas. Snow is infrequent. The frost-free period averages 200 days, but the effective growing season, when soil water and temperature are favorable, is often 90 days or less (Paulsen and Ares 1962).

Study areas were on shallow sand and sandy range sites (Table 1). Several soil series are included, all of which are in the thermic, typic Paleorthid, or Haplargid families (Bullock and Neher 1980). All of the study areas on both the JER and CR have been grazed by cattle at light to moderate rates (20-35\% use of key species) for many years.

On both the JER and CR the study areas had been treated with either monuron [3-(p-chlorophenyl)-1,1-dimethylurea] or fenuron (1,1-dimethyl-3-phenylurea) applied to individual plants, 2,4,5-T [2,4,5-trichlorophenoxy)acetic acid] aerially sprayed, or bulldozed between 1958 and 1964 (Table 1). Sampling to determine mesquite density was first done in 1976 on the JER and in 1982 on the CR. Mesquite density was again determined in 1988 on all areas.

On the JER, density of mesquite was determined on 5 randomly located (a new random set for each sampling, $3 \mathrm{~m} \times 305 \mathrm{~m}$ plots in 10 herbicide treated areas. Density was also determined on 5 randomly located plots $(3 \mathrm{~m} \times 305 \mathrm{~m}$ ) on 2, 8-ha areas, 1 bulldozed and the other treated with fenuron. On these latter 2 areas, percentage of mesquite killed by original treatments was near $100 \%$ (JER unpublished data). On the CR, mesquite density was determined on 15 randomly located, permanent plots $\left(12.2 \times 68 \mathrm{~m}\right.$ or $\left.830 \mathrm{~m}^{2}\right)$.

All mesquite plants within the plots were counted. Plants at the edge of the plots were counted if more than $50 \%$ of the base and canopy were in the plot. On the JER, canopy diameter was measured on each plant and recorded by size class. On the CR, diame- 
Table 1. Field-scale chemical and mechanical treatments for mesquite control on the Jornada Experimental Range (JER) and NMSU College Ranch (CR).

\begin{tabular}{|c|c|c|c|c|c|c|c|}
\hline Location & Treatment & $\begin{array}{l}\text { Year of } \\
\text { treatment }\end{array}$ & $\begin{array}{l}\text { Hectares } \\
\text { treated }\end{array}$ & $\begin{array}{l}\text { Orginal mesquite } \\
\text { density No./ha }\end{array}$ & $\%$ killed & $\begin{array}{l}\text { No./ha } \\
\text { surviving }\end{array}$ & Range site \\
\hline JER & Fenuron & 1958 & 40 & 331 & 82 & 60 & Sandy \\
\hline JER & Fenuron & 1959 & 121 & 156 & 80 & 31 & Sandy \\
\hline JER & Bulldozing & $1959 \& 60$ & 8 & NA & 100 & & Sandy \\
\hline JER & Fenuron & $1960 \mathrm{~A}$ & 8 & NA & 100 & & Sandy \\
\hline JER & Fenuron & 1960B & 142 & 190 & 94 & 11 & Sandy \\
\hline JER & Fenuron & 1962 & 625 & 32 & 20 & 26 & Sandy \\
\hline JER & Fenuron & 1963 & 305 & 82 & 70 & 25 & Shallow sand \\
\hline JER & Fenuron & 1964 & 173 & 173 & 79 & 36 & Shallow sand \\
\hline JER & Fenuron & 1965 & 209 & 136 & 74 & 35 & Shallow sand \\
\hline JER & Monuron & 1961 & 739 & 12 & 53 & 6 & Sandy \\
\hline JER & Monuron & 1962 & 288 & 35 & 36 & 22 & Sandy \\
\hline JER & $2,4,5-\mathrm{T}$ & $1959 \& 61$ & 40 & NA & 49 & & Sandy \\
\hline CR & Monuron & 1964 & $>200$ & $<100$ & $65-85$ & $15-35^{1}$ & Shallow sand \\
\hline
\end{tabular}

INA = Not available

'Surviving mesquite per hectare is based on an original density of $100 /$ ha

ter and height of each plant were measured and recorded. Canopy cover was calculated using mid-points of size classes. A Student $t$ test was used to determine whether mean mesquite densities differed between sampling dates on each area.

\section{Results and Discussion}

Mesquite densities were low to moderate on all areas at the time of original treatment and nearly all treatments resulted in substantial reductions in densities (Table 1). The fenuron treatments were least effective in 1962, a year of high precipitation (Fig. 1).

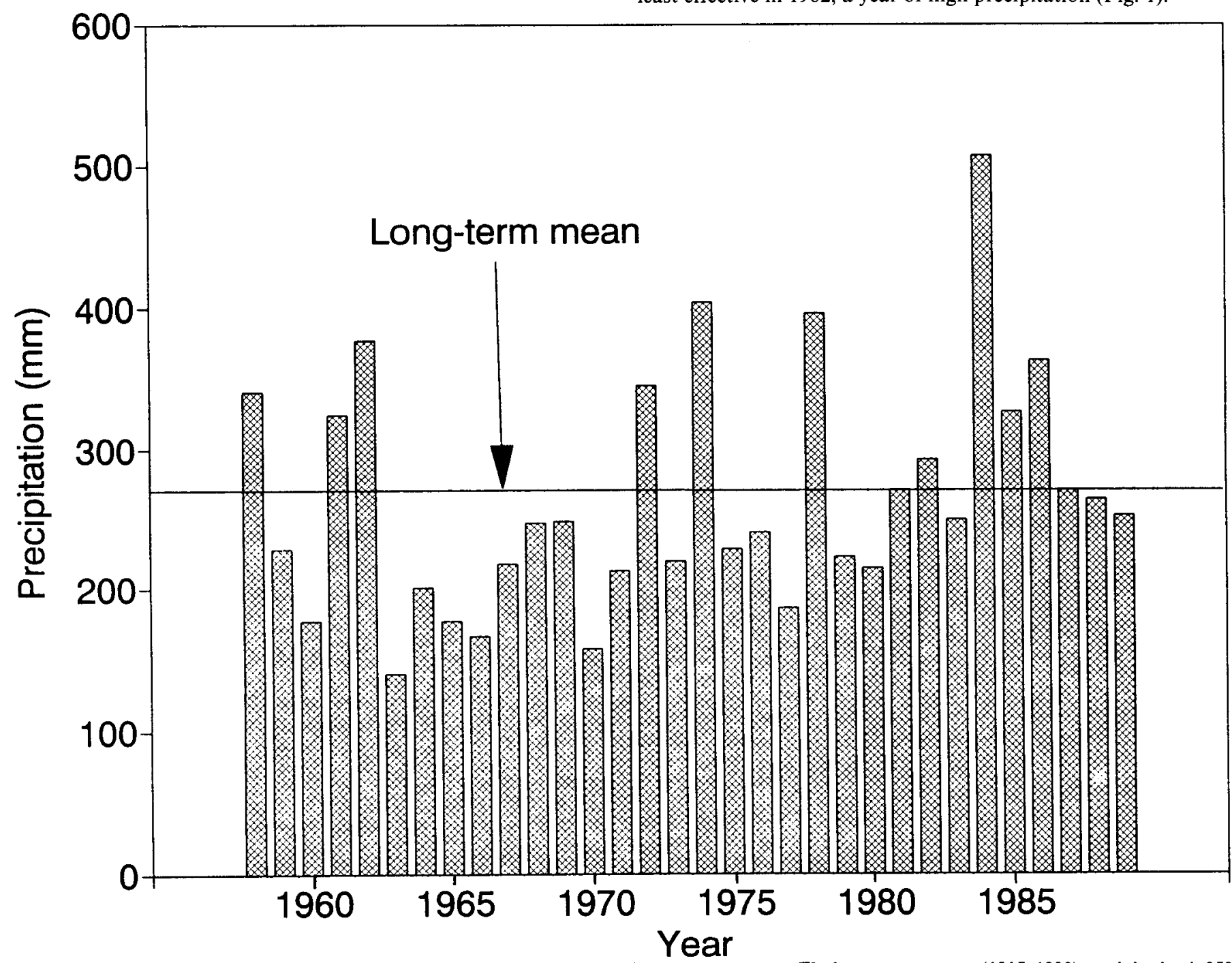

Fig. 1. Annual precipitation from 1958 to 1989 at the Jornada Experimental Range headquarters. The long-term average (1915-1990) precipitation is 259 mm. 
Table 2. Mesquite densities, probabilities $(P)$ of differences between beginning and ending total densities, rates of increase and canopy cover on Jornada Experimental Range (JER) and College Ranch (CR) sites.

\begin{tabular}{|c|c|c|c|c|c|c|c|c|c|c|c|}
\hline \multirow[b]{2}{*}{ Site } & \multirow[b]{2}{*}{ Year } & \multicolumn{6}{|c|}{ Size class } & \multirow[b]{2}{*}{$\mathbf{P}$} & \multirow[b]{2}{*}{ Increase } & \multirow[b]{2}{*}{ Rate } & \multirow[b]{2}{*}{ Canopy cover } \\
\hline & & $0-.6 \mathrm{~m}$ & $.6-1.2 \mathrm{~m}$ & $1.2-1.8 \mathrm{~m}$ & $1.8-2.4 \mathrm{~m}$ & $>2.4$ & Total & & & & \\
\hline JER Fenuron 1958 & $\begin{array}{l}1976 \\
1988\end{array}$ & $\begin{array}{c}-.-. \\
49 \\
80\end{array}$ & $\begin{array}{r}179 \\
86\end{array}$ & $\begin{array}{c}-- \text { (No. } \\
56 \\
140\end{array}$ & $\begin{array}{c}\text { (ha) } \ldots-.- \\
17 \\
28\end{array}$ & 26 & 327 & $\begin{array}{l}\text { (Total) } \\
>0.05\end{array}$ & $\begin{array}{r}(\%) \\
11\end{array}$ & $\begin{array}{c}\text { No. } / \mathrm{ha}^{-1} / \mathrm{yr}^{-1} \\
3.0\end{array}$ & $\begin{array}{r}(\%) \\
4 \\
6\end{array}$ \\
\hline JER Fenuron 1959 & $\begin{array}{l}1976 \\
1988\end{array}$ & $\begin{array}{l}13 \\
73\end{array}$ & $\begin{array}{l}80 \\
30\end{array}$ & $\begin{array}{l}80 \\
54\end{array}$ & $\begin{array}{l}17 \\
33\end{array}$ & $\begin{array}{r}8 \\
30\end{array}$ & $\begin{array}{l}198 \\
220\end{array}$ & $>0.05$ & 11 & 1.8 & $\begin{array}{l}3 \\
4\end{array}$ \\
\hline $\begin{array}{l}\text { JER Bulldozed } \\
1959-60\end{array}$ & 1988 & 204 & 108 & 56 & 4 & 0 & 372 & & 100 & 13.3 & 2 \\
\hline JER Fenuron 1960A & 1988 & 108 & 192 & 75 & 6 & 0 & 381 & & 100 & 13.6 & 3 \\
\hline JER Fenuron 1960B & $\begin{array}{l}1976 \\
1988\end{array}$ & $\begin{array}{c}9 \\
24\end{array}$ & $\begin{array}{l}65 \\
47\end{array}$ & $\begin{array}{l}49 \\
39\end{array}$ & $\begin{array}{r}4 \\
19\end{array}$ & $\begin{array}{r}2 \\
28\end{array}$ & $\begin{array}{l}129 \\
157\end{array}$ & $>0.05$ & 22 & 2.3 & $\begin{array}{l}2 \\
3\end{array}$ \\
\hline JER Fenurọn 1962 & $\begin{array}{l}1976 \\
1988\end{array}$ & $\begin{array}{r}37 \\
155\end{array}$ & $\begin{array}{l}58 \\
58\end{array}$ & $\begin{array}{l}17 \\
37\end{array}$ & $\begin{array}{r}8 \\
17\end{array}$ & $\begin{array}{l}24 \\
17\end{array}$ & $\begin{array}{l}144 \\
284\end{array}$ & $<0.01$ & 97 & 11.7 & $\begin{array}{l}2 \\
3\end{array}$ \\
\hline JER Fenuron 1963 & $\begin{array}{l}1976 \\
1988\end{array}$ & $\begin{array}{l}24 \\
39\end{array}$ & $\begin{array}{l}37 \\
43\end{array}$ & $\begin{array}{l}19 \\
41\end{array}$ & $\begin{array}{r}4 \\
15\end{array}$ & $\begin{array}{l}0 \\
6\end{array}$ & $\begin{array}{r}84 \\
144\end{array}$ & $<0.01$ & 71 & 5.0 & $\begin{array}{l}1 \\
2\end{array}$ \\
\hline JER Fenuron 1964 & $\begin{array}{l}1976 \\
1988\end{array}$ & $\begin{array}{l}26 \\
22\end{array}$ & $\begin{array}{r}8 \\
35\end{array}$ & $\begin{array}{r}0 \\
19\end{array}$ & $\begin{array}{l}0 \\
6\end{array}$ & $\begin{array}{l}2 \\
0\end{array}$ & $\begin{array}{l}36 \\
82\end{array}$ & $<0.01$ & 128 & 3.8 & $\begin{array}{r}<1 \\
1\end{array}$ \\
\hline JER Fenuron 1965 & $\begin{array}{l}1976 \\
1988\end{array}$ & $\begin{array}{l}20 \\
21\end{array}$ & $\begin{array}{l}11 \\
37\end{array}$ & $\begin{array}{l}4 \\
9\end{array}$ & $\begin{array}{l}4 \\
0\end{array}$ & $\begin{array}{l}2 \\
0\end{array}$ & $\begin{array}{l}41 \\
67\end{array}$ & $<0.01$ & 63 & 2.2 & $\begin{array}{l}<1 \\
<1\end{array}$ \\
\hline JER Monuron 1961 & $\begin{array}{l}1976 \\
1988\end{array}$ & $\begin{array}{r}26 \\
120\end{array}$ & $\begin{array}{l}60 \\
73\end{array}$ & $\begin{array}{l}35 \\
54\end{array}$ & $\begin{array}{l}15 \\
22\end{array}$ & $\begin{array}{l}30 \\
19\end{array}$ & $\begin{array}{l}166 \\
288\end{array}$ & $<0.05$ & 73 & 10.2 & $\begin{array}{l}3 \\
3\end{array}$ \\
\hline JER Monuron 1962 & $\begin{array}{l}1976 \\
1988\end{array}$ & $\begin{array}{r}50 \\
200\end{array}$ & $\begin{array}{r}77 \\
155\end{array}$ & $\begin{array}{l}39 \\
75\end{array}$ & $\begin{array}{r}32 \\
9\end{array}$ & $\begin{array}{l}32 \\
24\end{array}$ & $\begin{array}{l}230 \\
463\end{array}$ & $<0.01$ & 101 & 19.4 & $\begin{array}{l}4 \\
3\end{array}$ \\
\hline $\begin{array}{l}\text { JER } 2,4,5-T 1959 \& \\
\end{array}$ & $\begin{array}{l}1976 \\
1988\end{array}$ & $\begin{array}{r}90 \\
148\end{array}$ & $\begin{array}{r}142 \\
99\end{array}$ & $\begin{array}{l}123 \\
136\end{array}$ & $\begin{array}{l}41 \\
56\end{array}$ & $\begin{array}{l}52 \\
54\end{array}$ & $\begin{array}{l}448 \\
493\end{array}$ & $>0.05$ & 10 & 3.8 & $\begin{array}{l}7 \\
8\end{array}$ \\
\hline CR Monuron 1964 & $\begin{array}{l}1982 \\
1988\end{array}$ & $\begin{array}{l}72 \\
40\end{array}$ & $\begin{array}{l}31 \\
50\end{array}$ & $\begin{array}{r}9 \\
30\end{array}$ & $\begin{array}{r}6 \\
12\end{array}$ & $\begin{array}{l}12 \\
15\end{array}$ & $\begin{array}{l}130 \\
147\end{array}$ & $<0.001$ & 13 & 2.8 & $\begin{array}{l}1 \\
2\end{array}$ \\
\hline
\end{tabular}

Mesquite increased in density on all of the study areas (Table 2). The increase in density was significant $(P<0.05)$ except on JER Fenuron 1958, JER Fenuron 1959, JER Fenuron 1960B, and JER 2,4,5-T 1959 and 61 . There was a 10 to $22 \%$ increase in mesquite density on the areas without significant $(P>0.05)$ increases. On areas with significant $(P<0.05)$ increases in density, the percentage increase in mesquite density ranged from 13 to $128 \%$ (Table 2). While not always significant, the increase in mesquite density was consistent across areas differing widely in original mesquite density on both sandy and shallow sand range sites. This consistent increase probably reflects the relatively large number of years with above-average precipitation in the 1970's and 1980's (Fig. 1). From 1970 to $1988,50 \%$ of the years had precipitation above average while from 1915 to 1969 only $29 \%$ of years had above-average precipitation.

There was in increase in smaller $(<0.6 \mathrm{~m}$ diameter), and presumably younger, plants on 9 of the study areas, indicating recent establishment (Table 2). Statistical comparisons of size classes were not made because of low numbers, particularly in larger size classes. There was also a shift of small size classes into larger ones, indicating increase in plant size over time, e.g., JER Fenuron 1958 and CR Monuron 1964 (Table 2). During the 6-year period between measurements on the CR there was a striking increase in average plant diameter from 0.99 to $1.25 \mathrm{~m}$ and average plant height from 0.45 to $0.73 \mathrm{~m}$. The increase in plant size reflects the above-average precipitation which occurred in all 6 years (Fig. 1). We do not know at what age or size mesquite plants begin to produce seed but an increase in seed-producing plants would certainly accelerate increases in density. Mesquite canopy cover was $3 \%$ or less on most of the study areas (Table 2). On the JER 1959 and 61 2,4,5-T area, where large plants were relatively abundant, canopy cover was $8 \%$

For the 12-year period from 1976 to 1988 , the rate of increase in mesquite density ranged from 1.8 (Fenuron 1959) to 19.4 (Monuron 1962) plants/ha/year. The rate of increase was $13.6 \mathrm{plants} / \mathrm{ha} / \mathrm{yr}$ for JER Fenuron 1960A and 13.3 plants/ha/yr for JER Bulldozed 1959-60 over the 28-year period. Rate of increase on the CR area between 1982 and 1988 was 2.8 plants/ha/yr. Wide variations in establishment rates among sites are expected because of the localized nature of summer rains which influence amount of herbaceous cover, success of mesquite seed production, seed germination, and seedling establishment. Shrubs are adapted for establishment in both drought and high rainfall years (Friedel 1991).

On the Santa Rita Experimental Range (SRER) in Arizona, velvet mesquite densities increased in a 17-year period (calculated from data presented by Glendening 1952) at rates of 9.2 plants/ $\mathrm{ha} / \mathrm{yr}$ on areas open to cattle and rodents and at $15.7 \mathrm{plants} / \mathrm{ha} / \mathrm{yr}$ on areas with cattle and rodents excluded. Also on the SRER, Glendening and Paulsen (1955) reported velvet mesquite densities increased at rates of 4.4 to 26.7 plants/ha/yr on plots protected from cattle for 18 to 25 years. Both minimum and maximum rates of mesquite establishment were higher on the SRER than those found in the Jornada Basin but mean annual rainfall is $61 \mathrm{~mm}$ higher on the SRER than in the Jornada Basin. The mesquite establishment rates found in the Jornada Basin are high enough to be of major concern to land managers.

A fortuitous event permitted some field observations of the fate of mesquite seedlings. Large numbers of mesquite seedlings germinated in the track of a rainstorm on the JER which occurred on 31 July 1989 . Over 100 of these seedlings were individually marked in areas where livest ock were excluded (JER files). Of the 89 seedlings relocated the following May, $2 \%$ had succumbed to drought and 
the dry stems were still present. Another $79 \%$ of the seedlings were dead because they had been bitten off, presumbly by lagormorphs, at or slightly below the cotyledonary node, which causes death (Meyer et al. 1971). All of the living seedlings had been partially bitten-off and new growth was from axillary buds. Lagomorphs or other herbivores can obviously play an important role in limiting the establishment of mesquite. However, as in this case, some seedlings usually survive and contribute to a steadily increasing population of mesquite plants.

\section{Conclusions}

This study shows that mesquite has increased in recent years even on well-managed rangelands where stocking has been light to moderate. Years when mesquite can become established obviously occur quite frequently, although in a spatially discontinuous pattern. Unless effective mesquite control measures are implemented fairly frequently, large areas still dominated by grasses are likely to become coppice dunelands. Control efforts such as those carried out from 1958 to 1965 can reduce mesquite populations. However, the mesquite establishment rate is so rapid that control efforts must be repeated at 20-30 year intervals. Failure to implement control efforts will result in a reduction of forage for livestock and loss of habitat for pronghorn antelope (Antilocapra americana) and other grassland-dependent species.

\section{Literature Cited}

Brown, J.R., and S. Archer. 1987. Woody plant seed dispersal and gap formation in a North American subtropical savanna woodland: the role of domestic herbivores. Vegetatio 73:73-80.

Brown, J.R., and S. Archer. 1989. Woody plant invasion of grasslands: establishment of honey mesquite (Prosopis glandulosa var. glandulosa) on sites differing in herbaceous biomass and grazing history. Oecologia 80:19-26.

Buffington, L.C., and C.H. Herbel. 1965. Vegetation changes on a semidesert grassland range from 1858 to 1963. Ecol. Monog. 35:139-164.

Bullock, H.E., Jr., and R.E. Neher. 1980. Soil survey of Dona Ana County area of New Mexico. SCS, USDA in cooperation with Bur. Land Manage. and N.M. Agr. Exp. Sta.
Glendening, G.E. 1952. Some quantitative data on the increase of mesquite and cactus on a desert grassland range in southern Arizona. Ecology 33:319-328.

Glendening, G.E., and H.A. Paulsen. Jr. 1955. Reproduction and establishment of velvet mesquite as related to invasion of semidesert grasslands. USDA Tech. Bull. No. 1127.

Friedel, M.H. 1991. Range condition assessment and the concept of thresholds: a viewpoint. J. Range Manage. 44:422-426.

Hastings, J.R., and R.M. Turner. 1965. The changing mile: an ecological study of vegetation change with time in the lower mile of an arid and semi-arid region. Univ. Arizona Press, Tucson.

Humphrey, R.R. 1958. The desert grassland. Bot. Rev. 24:193-253.

Humphrey, R.R., and L.A. Mehrhoff. 1958. Vegetation changes on a southern Arizona grassland. Ecology 39:720-726.

Martin, S.C., and R.M. Turner. 1977. Vegetation change in the Sonoran Desert region, Arizona and Sonora. J. Ariz. Acad. Sci. 12:59-69.

Meyer, R.E., H.L. Morton, R.H. Haas, E.D. Robison, and T.E. Riley. 1971. Morphology and anatomy of honey mesquite. USDA Tech. Bull. 1423.

Paulsen, H.A., Jr., and F.N. Ares. 1962. Grazing values and management of black grama and tobosa grasslands and associated shrub ranges of the Southwest. USDA Forest Serv. Tech. Bull. 1270.

Reynolds, H.G., and G.E. Glendening. 1949. Merriam kangaroo rat a factor in mesquite propagation on southern Arizona range lands. $J$. Range Manage. 2:193-297.

Scifres, C.J., and J.H. Brock. 1969. Moisture-temperature interelations in germination and early seedling development of mesquite. J. Range Manage. 22:334-337.

Scifres, C.J., and J.H. Brock. 1971. Thermal regulation of water uptake by germinating honey mesquite seeds. J. Range Mange. 25:157-158.

Scifres, C.J., C.R. Kienart, and D.L. Elrod. 1973. Honey mesquite seedling growth and 2,4,5-T susceptibility as influenced by shading. J. Range Manage. 26:58-60.

Ueckert, D.N., L.L. Smith, and B.L. Allen. 1979. Emergence and survival of honey mesquite seedlings on several soils in west Texas. J. Range Manage. 32:284-287.

Wright, H.A., and A.W. Bailey. 1982. Fire ecology. John Wiley \& Sons, N.Y.

Wright, R.A. 1982. Aspects of desertification in Prosopis dunelands of southern New Mexico, U.S.A. J. Arid Environ. 5:277-284.

York, J.C., and W.A. Dick-Peddie. 1969. Vegetation changes in southern New Mexico during the past hundred years. p. 157-166. In: W.G. McGinnies and B.J. Goldman (ed.) Arid lands in perspective. Univ. of Arizona Press, Tucson. 